References

1. Bodak, V. A. (2006). Religion as Phenomenon of Universum of Culture: Christian context. Extended abstract of doctor's thesis. Kyiv: H. S. Skovoroda Philosophy Institute [in Ukrainian].

2. Kunzler, M. (2001). Liturgy of the Church. (Nun Sofia, Trans). Lviv: Svichado [in Ukrainian].

3. Mechkovskaya, N. (1998). Language and religion. Lectures on philology and history of religions. Moscow: Torgovyj dom Grand [in Russian].

4. Popovych, M. V. (1998). Essay on the history of Ukrainian culture. Kyiv: ArtEk [in Ukrainian].

5. Rabus, A. (2010). Translation or transfer? Spiritual songs between language sacredness and popularity // $\mathrm{KA} \wedge О Ф \Omega$ NIA. Scientific collection on the history of church monody and hymnography, 5, 196-204 [in Ukrainian].

6. Sheluto, V. M. (2010). The problem of sacred in an aesthetic process. Extended abstract of doctor's thesis. Luhansk: Volodymyr Dahl East-Ukrainian National University [in Ukrainian].

7. Liturgické jazyky v duchovnej kultúre Slovanov. Monotematický súbor štúdií (2017). P. Žeňuch P. et al. (Ed.). Bratislava [in Slovak].

8. Pawlak, I. (2001). Muzyka liturgiczna po soborze Watykańskim II w świetle dokumentów Kościoła (2 $2^{\text {th }}$ ed.). Lublin: Polihymnia [in Polish].

9. Stern, D. (2013). Tradition und Traditionalismus im konfessionellen Kontakt: Die ruthenischen geistlichen Lieder in ihrem Verhältnis zur byzantinisch-slavischen Hymnographie. Dedičstvo duchovnej piesňovej kultúry medzi slovanským Východom a Západom, 37-66 [in German].

Стаття надійшла до редакції 08.07.2018 p.

UDC $78.01+78.03+782$

Kaznacheieva Tetiana

$\mathrm{PhD}$ in Arts, assistant professor

The Department of Common and Specialized Piano

A.V. Nezhdanova Odessa State Musical Academy

ORCID: 0000-0002-8692-2844

itaniamusic@gmail.com

\title{
PRE-SCENIC MUSICAL AND DANCE GENRES AND FORMS OF THE MIDDLE AGES
}

The purpose of the work. The article considers the main pre-scenic musical and dance genres and forms of the Middle Ages, which formed the basis for the emergence of classical examples of musical, dance and opera-theatrical art in the further historical development. For the purposeful disclosure of the most important trends characteristic of this period, the problem of the interaction of music and dance in the context of the most complicated panorama of secular professional and synthetic, transitional (preceding scenic) dance and musical forms were analyzed. The methodology of the research consists of a set of historical, systemic and integrated methods. The scientific novelty of the work consists in the expansion of comprehension of the peculiarities of the formation of various genres of music and dance arts, as well as to substantiation of the continuity of the traditions of the historical inheritance of medieval pre-scenic forms leading to the origins of the formation and development of music and opera-theatrical arts. Conclusions. The history of the development of musical and dance genres demonstrates undeniable connections between the first dance experiments of prehistoric times and pre-scenic forms of the Middle Ages, leading then, through many centuries, up to the emergence of the fundamental genres of musical-theatrical art at the end of the Renaissance.

Keywords: the Middle Ages, music, dance, liturgical drama, mystery, theatrical processions, pre-scenic roundel forms, estampida, round dance, moresca.

Казначеєва Тетяна Олександрівна, кандидат мистецтвознавства, в. о. доцента кафредри загального та спеціалізованого фортепіано Одеської національної музичної академії ім. А. В. Нежданової

Передсценічні музично-танцювальні жанри та форми епохи Середньовіччя

Мета роботи. У статті розглянуті основні передсценічні музично-танцювальні жанри і форми епохи Середньовіччя, що утворили фундамент для появи в ході подальшого історичного розвитку класичних зразків музичного, танцювального та оперно-театрального мистецтв. Для цілеспрямованого розкриття найбільш важливих тенденцій, характерних для зазначеного періоду, проаналізовано проблему взаємодії музики і танцю в контексті складної панорами світських професійних і синтетичних, перехідних (тих, що передували сценічним) танцювальних та музичних форм. Методологія дослідження складається із сукупності історичного, системного та комплексного методів. Наукова новизна роботи полягає в розширенні розуміння особливостей формування різних жанрів музичного та танцювального мистецтв, а також в обґрунтуванні історичного успадкування середньовічних передсценічних форм, що призводить до витоків становлення, розвитку музичного та оперно-театрального мистецтв. Висновки. Історія розвитку музично-танцювальних жанрів демонструє безсумнівні зв'язки між першими танцювальними дослідами доісторичних часів та передсценічними формами епохи Середньовіччя, що призводять потім, крізь багато століть, до появи в кінці епохи Відродження фундаментальних жанрів музично-сценічного мистецтва.

Ключові слова: Середньовіччя, музика, танець, літургійна драма, містерія, театралізовані процесії, передсценічні рондальні форми, естампіда, хороводні танці, мореска.

() Kaznacheieva T., 2018 
Казначеева Татьяна Александровна, кандидат искусствоведения, и. о. доцента кафедры общего и специализированного фортепиано Одесской национальной музыкальной академии им. А. В. Неждановой Предсценические музыкально-танцевальные жанры и формы эпохи Средневековья

Цель работы. В статье рассмотрены основные предсценические музыкально-танцевальные жанры и формы эпохи Средневековья, составившие фундамент для появления в ходе дальнейшего исторического развития классических образцов музыкального, танцевального и оперно-театрального искусств. Для целенаправленного раскрытия наиболее важных тенденций, характерных для указанного периода, проанализирована проблема взаимодействия музыки и танца в контексте сложнейшей панорамы светских профессиональных и синтетических, переходных (предшествовавших сценическим) танцевальных и музыкальных форм. Методология исследования состоит из совокупности исторического, системного и комплексного методов. Научная новизна работы заключается в расширении понимания особенностей фрормирования различных жанров музыкального и танцевального искусств, а также в обосновании преемственности традиций исторического наследования средневековых предсценических форм, приводящей к истокам становления, развития музыкального и оперно-театрального искусств. Выводы. История развития музыкально-танцевальных жанров демонстрирует несомненные связи между первыми танцевальными опытами доисторических времен и предсценическими фрормами эпохи Средневековья, ведущими затем, сквозь многие века, к появлению в конце эпохи Возрождения фундаментальных жанров музыкально-сценического искусства.

Ключевые слова: Средневековье, музыка, танец, литургическая драма, мистерия, театрализованные процессии, предсценические рондальные формы, эстампида, хороводные танцы, мореска.

Problem statement. The study of the origins of the formation of Western European dance traditions implies reference to the long past historical epochs, one of which is the Middle Ages.

A relevant theme of scientific developments is the analysis of worldview and artistic interrelations between different historical periods. The article by V. Karpov and N. Syrotynska [9] is devoted to the comprehension of the worldview and artistic forms of interaction of the Middle Ages and the modern times as an important factor in the context of formation of an integral historical and cultural model of the human development.

The book of a historian and poet K. A. Ivanov «Troubadours, Trouvères and Minnesingers» reveals the inner, spiritual life of the epoch embodied in the poetry of the European Middle Ages. M. Saponov, describing the representatives of the secular culture of this period, offers a classification of minstrels with various professional skills [6].

The experience of studying the history of music in the context of the formation of cultural traditions of Western Europe, including the facts from the life of medieval troubadours, which largely influenced the formation of the musical taste of their generation, is reflected in the publication of V. Zharkova [3]. A new view of the development of music in the context of the medieval intellectual world is presented in the work of $\mathrm{C}$. Ruini and V. Minazzi [10].

In the article about the first preserved written sources related to the art of dance, we are considering significant achievements in the field of creating a theory of art of dance and its «iconic» fixation $[4,422]$. At the same time, the issues of formation of the origins of Western European dance traditions in the Middle Ages still remains little studied. For the purposeful disclosure of the most important trends characteristic of the period, we need to analyze the problem of the interaction of music and dance in the context of the most complex panorama of secular professional and synthetic, transitional (preceding scenic) dance and musical forms.

The purpose of this article is to examine the pre-scenic musical and dance genres and forms of the Middle Ages, which formed the basis for the emergence of classical samples of musical, dance and operatheatrical art in the course of the further historical development.

Statement of basic materials. The dance culture, being a part of general culture and art, is in a constant interaction with such forms of public consciousness as philosophy and religion.

In the primary period of the existence of Christianity, strict noble sacred dances were recognized and distributed. The church service consisted of reading psalms, singing hymns and sacred songs, "God was glorified by recitation, singing and dancing» [7, 19]. The movements of the dances that were performed during the prayer were calm, slow and majestic: «Prayers walked back and forth in a straight line or along a circle, raising or lowering their hands, raising their eyes to the sky» [8, 272]. In the ancient temples of Europe there was a special platform, towering before the altar - the orchestra, where the dances of clergymen were performed (hereafter the choir and the special elevation for the soloist - gradual were located in this place of the temple). R. Gruber confirms that at the first stage of the formation of Christian music «both dance and performance on the musical instruments were used» [2, 353].

However, gradually the majority of religious dances begin to disappear. Clergymen start to prohibit a dance in general. It is considered worthless and immoral occupation. This opinion becomes the basis of the orthodox medieval worldview. Those dances near temples, which were particularly popular in this historical period, were constantly banned by the spiritual councils held in European countries.

An attempt to reunify music, dance and dramatic action on a professional basis is represented by a specific form of drama that became widespread in the IX - X centuries in many European countries and formed the basis of a peculiar «religious theater» - a liturgical drama («Bible drama»). By the presence of common compositional, structural features (interweaving of pantomime action, singing and dance perfor- 
mance accompanied by musical instruments), we can state that the origins of this form of drama go back to the Egyptian, Babylonian, Greek and Roman mass events.

The further development of the liturgical drama, with a more elaborate plot, contributed to the development of large-scale performances with themes of stories from the Old and New Testaments (the legend of Adam and Eve, the story of Moses, the passion of Jesus Christ, John the Baptist, Job the longsuffering and many others).

In the XIII century, mysteries from the life of saints (miracles, from Latin miraculum - miracle) appeared. This genre variety carries out a unique desire to convey and realize an idea of the divine in time and space through the art of music (singing, musical instruments), the use of the theatrical components (dramatic effects, the use of stage equipment, costumes) and the elements of the dance art (pantomime).

An intensive development of the genre variety of the mystery leads to the formation of a whole cycle of plays of religious content. Performances could last for several (from three to forty) days and turned into a bright, multi-component action. In the literature aspect mysteries were based on the texts written in Latin and local languages (English, Italian, German, etc.).

According to the Hungarian musicologists I. Balashsha and S. Gal, the mysteries in Italy acquire a completely opera form: «In some of them there are dance numbers. Outstanding Italian architects create magnificent equipment for the stage, and music in these performances becomes more and more dominant» [1, p. 14].

In the Middle Ages, street processions were widely spread. There were several of their varieties. The participation of equestrian riders was a distinctive feature of the cavalcade (from the Ital. verb cavalcare - to ride a horse). The basis of the script was an allegorical depiction of mythological and religious subjects.

Moving ballets were another variety of processions. They were based on processions in honor of religious holidays that were extremely popular throughout the European countries (in England, Germany, Italy, Portugal, France). They consisted of clergy, representatives of the nobility, individual types of troops and a large number of city residents. Dances were one of the main components of these processions. During the procession, both slow dance movements and cheerful dances were performed. We shall note that in the processions there was a certain scenario (based on mythological and biblical stories) and a fairly developed drama. They used a variety of costumes and symbolic attributes, chariots and mobile devices. The musical design of the processions was really significant, special attention was paid to the performance of dance elements. The abovementioned characteristics give grounds to state the features of theatricalization and staging of the processions.

Moreover, in the Middle Ages, a significant place in the cultural life of European cities was occupied by festive theatrical processions - carnivals. The roots of their origin date back to the ancient Greek Dionysians and the pagan customs of the Roman Empire. There was a «ship» ahead of the processions - "carrus navalis», i.e. a sea chariot. Games, staging, dances performed by the people dressed in bright, diverse costumes were an integral part of the carnivals. Grotesque, satirical images of carnival processions find their embodiment through codified movements that become symbols, a special language, some kind of «words». One of the favorite entertainments of the carnival were masquerades (Fr. mascarade from It. mascarata, mascherata, from It. Maschera - mask). A mask was an obligatory attribute used by participants in the dance. We shall note that there were street masquerades and masquerades of the high court society. The masquerades of the high society were presented by special balls, where participants appeared in various characteristic (fantastic, historical) costumes. Music was an organic part of this multi-component action, creating an atmosphere of fun and joy. In all the palace halls, small orchestras usually played. String and wind instruments were especially popular. Dance scenes of masquerades become original precursors of the ballet performances. For the performance of these short pantomimes with dances, dancers were required to have a certain degree of technical and performing skills. The movements of the arms and legs become more complex, jumps and acrobatics helped to bring out bizarre, often sarcastic images.

The most significant manifestations of the dance culture of the Middle Ages are connected, besides those considered, with two directions reflecting the most important features of the life of the particular social environment. First, it is an impressive layer of folk dance culture. Secondly - the dances, common in the courts of European monarchs, landowners, feudal lords and high clergy. Let us analyze their main genre varieties and forms (we shall specify that in the Middle Ages the concepts «genre» and «form» are practically inseparable).

In the XII - XIII centuries, on the basis of written sources, we can distinguish two categories of dances: slow, calm and faster, with jumps. The first dances were performed in palaces and courts. Vivid «dances with jumps and circular movements were performed to people by people» [8,309].

An ability to dance, sing and play musical instruments (for example, such as lute, viel) was an obligatory condition of the courtly social life. From the technical side, the performance of promenade (walking) dancing processions was not difficult. The nature of the movements was calm, solemn, the steps were gliding and smooth. The compositional pattern of the dance consisted of all possible transformations of a long chain of pairs. An example of promenade dances was a dance with torches - an indispensable part of court balls and knightly tournaments in Germany, Italy and France. Courtiers, carrying torches in their hands, were 
usually ahead of the solemn procession. They were followed by other pairs moving at a slow and smooth pace.

The folk dance culture of the Middle Ages differs in completely other ways. During folk festivals, dedicated to the arrival of spring, harvesting, the end of the calendar year and other events, dances were always performed. They mostly preserved the traces of various superstitions, ancient customs, and resembled games to a large extent. In each country, they had their own specific characteristics; they were largely a rethinking of authentic folk dance material. These are various social dances: domestic, urban and rural.

In France in the Middle Ages there was a dance of buffoons or comedians. In this choreographic battle with the use of swords, the love of the French for weapons and duels was embodied: «The dancers are dressed in short armor with fringe on the shoulders and on the belt, from under which the drapery of taffeta hangs, and in helmets of gilded carton; their hands are bare, they have bells on their legs, in their right hands they hold a sword, in the left - a shield. The dance was performed in a duple meter composed especially for it, punching swords and shields» [5, 125].

In the cities of Germany, workers and artisans united in «workshops», each of which had its own dance house. For example, the cooperage shop in Munich was famous for its original dance with hoops. Guild festivals, accompanied by a variety of dances were particularly popular. Dances performed in urban and rural areas were an indispensable component of the folk fairs of peasants and artisans.

A special role in the formation of music and dance genres of the Middle Ages belongs to numerous representatives of secular culture, which received significant development in this epoch. This is the creative activity of strolling actors - spielmanns (German Spielmann, from spielen - to play and Mann - man), Provencal troubadours (Fr. troubadour - from Provence trobador, from trobar - to find, to compose verses), poets and musicians trouveres, who composed in another French dialect and German knightly singers-poetsminnesingers (German Minnesinger - a singer of love) and Etruscan gistrions (mimic dancers).

Their works combined various arts: acting, musical, poetic, dance, and some - also circus (acrobatic, juggling). The unique activity of such artists contributed to the improvement of the performing dance skills and the complication of a dance technique practically throughout Europe. Their creative activity resulted in the iconic phenomena in the evolution of musical forms and in the development of the song and dance genres of Western European art.

Rondo, ballade and virelay became the main genre varieties, pre-scenic dance forms of the Middle Ages. In essence, they are dance songs and refer to rondal forms. Their main characteristic features are the repetition of poetic and musical lines. These song and dance forms are a unique manifestation of the syncretism of musical, poetic and dance arts. The musical and poetic stanzas are interconnected in a very special way: poetic and melodic phrases develop in parallel, an inner relationship with the rhyme and a regular repeatability of the lines are felt. The artist illustrated the song with the movements of the dance. A close connection of the musical and poetic components determines the main feature of the dances, which accompanied medieval songs. This feature is the predominance of a circular motion.

Rondal dance forms are works already sufficiently professional, secular, however, their connection with folk art is beyond any doubt.

Estrampida or Estampi (French estampie, Latin stantipes, German Estempida) is a musical and poetic form, as well as instrumental dance of a French origin (from Provence). In England, Germany and Italy, it was called istanpitta. According to many researchers (Johannes de Grocheio, G. Riemann, V. Vasilevsky, T. Baranova), estampida in its through-composed stanza form is close to such vocal genres of medieval music as sequence, les, chanson de geste, ballade of troubadours and trouveres.

Male, female or mixed round dances were the most common in the Middle Ages.

A round dance (from Greek choreia - dance) is one of the most ancient kinds of the folk dance art. Genre varieties of round dances of the Middle Ages are: carole, farandole, branle. Dance dances of European nations differ in some features. There were different variants of round dances, which movements expressed the spirit and temperament of a certain people (and even individual localities). The basis of the pattern of the dance was: a circle (the performers of the dance held each other by the hands, or the hands were on the hips) or a chain (in this case the dance was conducted by the male or female presenter). The main movement used in formation of the dance was a step, sometimes a leap. The singing of the dancers themselves was an accompaniment of the dance. We shall emphasize that initially the majority of folk round dance (and not only) dances were performed under recitation. The monotonous singing of the dancers resembled a recitative.

In the late Middle Ages (by the XIII century), a pair dance appeared. Initially, it was defined as an evasion from the form of a round dance, then - as an expression of feelings between a man and a woman. The pace of pair dances changed from smooth, slow to faster, lively. The musical meter was often variable (2/4 and 6/8). The pairs lined up in a row or line, the dance moves became more complex. The musical accompaniment of the dances was performed by various instruments (most often - varieties of wind and percussion, sometimes - a small orchestra).

In the high society in medieval Europe (in Germany, Italy and France) small dance scenes, which were called entre (Entrée from Fr. - entrance) became popular. They were a part of a performance for the guests at balls and feasts, which feudal lords arranged in the palace halls. During the festivals, certain regu- 
lations were observed. Songs were performed under the accompaniment of various instruments. During the break between serving various dishes masked characters appeared in the banquet hall. The invited dancers performed dance performances. Moresca was a typical example of such kind of action.

Moresca (Italian moresca, morisca, English morris dance, lit. - Moorish dance) is a small musical and dance scene. In the Middle Ages in England and Italy, moresca was a necessary component of every fest. To resemble the Moors, the performers of the stage painted their faces with dark paint and put on their dresses with bells. The performance of moresca besides dances included performances of singers-soloists, who explained the plot. The timing is duple. A person performing moreska, «all the time rests on toes, tapping his heels, producing sound by bells» $[5,124]$.

Conclusions. The considered tendencies of the music and dance culture of the Middle Ages precede the emergence of everyday, stage dances during the Renaissance, which formed the basis for the formation of classical models of music, dance and theatrical arts in the course of the further historical development.

In particular, we should note that in some episodes of the mysteries, the initial appearance and formation of a dance component of future theatrical performances took place in various types of theatrical processions (processions in honor of religious holidays, carnivals, cavalcades); it is possible to determine the features of theatricalization and staging. Through the form of these theatrical performances down the ages, since prehistoric times, a peculiar thread, leading from the first dance experiments to the Middle Ages, and then to the emergence of the fundamental genres of musical-theatrical art at the end of the Renaissance can be traced. Numerous genre varieties, pre-scenic dance forms of the Middle Ages - rondal, round dance - created the basis for the emergence of classical models of music, dance and opera and theatrical arts in the course of the further historical development.

\section{תimepamypa}

1. Балашша И. Путеводитель по операм / пер. с венгерского. 2-е испр. изд. Будапешт: Корвина, 1967. Ч. 1. $435 \mathrm{c}$.

2. Грубер Р. И. История музыкальной культуры: в 2 т. М.; Л.: Музгиз, 1941. Т. 1: С древнейших времен до конца XVI века. 595 с.

3. Жаркова В. Десять взглядов на историю западноевропейской музыки. Тайны и желания Ното Musicus. K.: ArtHuss, 2018. T. 1. 440 c.

4. Казначеева Т. А. Эволюция методов фриксации танцевальных движений. Музичне мистецтво і культура: Науковий вісник Одеської національної музичної академії імені А. В. Нежданової, 2014. Вип. 19. С. $422-432$.

5. Оркезография, или Трактат о танце в форме диалога, с помощью которого каждый может легко изучить благородное искусство танца и практиковаться в нем, написанный Туано Арбо, жителем Лангра / пер. П. Райгородского. Музыкальная академия. 1999. №2. С. 119-126.

6. Сапонов М. Менестрели. Книга о музыке средневековой Европы. М: Классика-XXI, 2006. 400 с.

7. Танцы, их история и развитие (по изданию Г. Вюилье). С. - Петербург: Типография А. С. Суворина, 1902. $121 \mathrm{c}$.

8. Худеков С. Н. Искусство танца: История. Культура. Ритуал. М.: Эксмо, 2010. 544 с.

9. Karpov V., Syrotynska N. Medieval and contemporaneity world-visual and art parallels. Вісник Національної академії керівних кадрів культури і мистецтва: наук. журнал. К.: Міленіум, 2018. № 2. С. 177-182. 2011. $280 p$.

10. Ruini C., Minazzi V. Musica: geistliche und weltliche Musik des Mittelalters. Freiburg; Basel; Wien: Herder,

\section{References}

[in Russian].

1. Balashsha I. (1967). Guide to operas / trans. from Hungarian. 2 nd correction. ed. Budapest: Korvina. P. 1.

2. Gruber R. I. (1941). The history of musical culture: in 2 vols. Vol. 1: From ancient times to the end of the XVI century. M.; L.: Muzgiz [in Russian].

3. Zharkova V. (2018). Ten views on the history of Western music. Secrets and Desires of Homo Musicus. Vol. 1. Kyiv: ArtHuss [in Russian].

4. Kaznacheieva, T. (2014). Evolution of methods for fixing the dance movements. Music art and culture, 19, 422-432. Odessa: Astroprint [in Russian].

5. Orkezografiya, or Treatise on dance in the form of a dialogue, through which everyone can easily learn the noble art of dance and practice in it, written by Tuano Arbo, a resident of Langre / trans. P. Raygorodsky. Musical Academy, 1999, 2. 119-126 [in Russian].

Russian].

6. Saponov M. (2006). Minstrels. A book about the music of medieval Europe. Moscow: Klassika-XXI [in

7. Dances, their history and development (according to the edition of G. Vyuile). (1902). S. - Peterburg: Tipografiya A. S. Suvorina [in Russian].

8. Hudekov S. N. (2010). The art of dance: History. Culture. Ritual. Moscow: Eksmo [in Russian].

9. Karpov V., Syrotynska N. (2018). Medieval and contemporaneity world-visual and art parallels. Bulletin of the National Academy of Managerial Staff of Culture and Arts, 2, 177-182 [in English].

10. Ruini C., Minazzi V. (2011). Musica: geistliche und weltliche Musik des Mittelalters. Freiburg; Basel; Wien: Herder [in German]. 